\title{
Alter-transitional justice; transforming unjust relations with the more-than-human
}

\author{
Danielle Celermajer* \\ Department of Sociology and Social Policy, Sydney Environment Institute, University of Sydney
}

\author{
Anne Therese O’Brien** \\ Independent researcher
}

Drawing on the emerging field of multispecies justice, this article seeks to understand how the idea of transitional justice, capaciously understood, might be put to work to transform unjust relations between humans and the more-than-human. Reflecting on concerns in the literatures on animals and the environment concerning the cogency of addressing past wrongs against the more-than-human by using a justice framework, the article sets out a foundational agenda for transitional justice and a conceptual framework responsive to the ontological diversity of beings and communities other than humans. Focusing on soil specifically, the article explores the problem of developing transitional justice approaches for transforming relations that involve systemic violence where such violence is not acknowledged because the harmed being - soil - is not recognized as the type of community to which justice might be owed. To illustrate prototransitional justice, the article considers both the work of regenerative farmers and emergent collaborations between farmers and visual artists to explore how engagements with the arts of relating to the more-than-human might move the as yet private transformations of relations with soil into a more public, albeit incipient, process of justice.

Keywords: transitional justice, more-than-human, multispecies justice, soil integrity, regenerative agriculture, care, new materialism

\section{INTRODUCTION}

When Robert Cover depicted law as 'a bridge linking a concept of reality to an imagined alternative', ${ }^{1}$ he stipulated that the formal dimension of law, the corpus juris, is nourished by myths and narratives. By implication, the transformation of myths and narratives makes possible the transition from what is to what might be. Importantly for our topic, which concerns the prospect of addressing the systemic violence that characterizes

* Danielle.celermajer@sydney.edu.au

**anneobr@gmail.com

1. RM Cover, 'Foreword: Nomos and Narrative' (1983) 97 Harvard Law Review 4, at 9. It was Charlotte Blattner's use of Cover's framing in her analysis of transitional justice for interspecies society that had us return to his work and recognize its pertinence for framing our arguments. See C Blattner, 'Drafting Principles for Transitional Justice for an Interspecies Society' (Harvard University 2019). 
relations between humans and the more-than-human world, he also suggested that these myths and narratives 'build relations between the normative and the material universe'.

This article emerges from our broader interest in justice for the more-than-human and, in particular, work that we have been undertaking in developing the field of multispecies justice. ${ }^{3}$ To date, that field has for the most part been concerned with present and future relations, and with what type of institutional arrangements would better promote and protect justice for all humans, other animals and the environment. In light of a longstanding interest that one of us has had in how collectives deal with past systemic wrongs, here we extend this work and seek to understand how the idea of transitional justice, capaciously understood, might be put to work to think through how to build a bridge between the unjust reality of human relations with the more-than-human and new forms of relationship that would support the flourishing of humans and the more-than-human. ${ }^{4}$ Given the vastness of the chasm between existing unjust and aspirational just relations between humans and beings other than humans, where Cover imagined a bridge, one might perhaps imagine an unmarked track between two different worlds: at one end, the unjust and violent reality that is comprehensively instantiated in dominant myths and across a comprehensive range of social, political, economic institutions, and at the other a possible future that has at best a tenuous hold even on the imagination.

Our goal is to explore and to suggest how this track might be forged, both at a relatively abstract level and then with respect to one particular part of the more-thanhuman world: soil. We have chosen soil for several reasons, which we will discuss below, but in the first instance precisely because it lies at the far side of the category of lifeforms that occur to (most) humans as morally considerable. ${ }^{5}$ Indeed, despite the systemic harms that common human practices cause to soil, to a large extent, most people fail to register that such practices involve any wrongdoing. Soil ill fits within conventional notions of a moral subject, and hence presents a particular challenge to habitual imaginaries of what it might mean to enter into a set of transformative justice processes. At the same time, being inherently relational, soil offers a radical challenge for reimagining who and what might form part of a moral community, and for the types of myths, narratives and imaginaries that would be needed to nourish such a community.

The article commences with a theoretical discussion of transitional justice as a constitutive form of justice, paying particular attention to the 'imaginative stretch' that would be required to bring the idea of transitional justice to largely unacknowledged forms of violence against beings other than humans. In the next part of the

2. Cover (n 1). Throughout this article, we use the term 'systemic' to denote forms of violence that are produced and sustained by structures or institutions. Systemic violence is thereby embedded and normalized.

3. See D Celermajer, D Schlosberg, L Rickards, M Stewart-Harawira, M Thaler, P Tschakert, B Verlie and C Winter, 'Multispecies Justice: Theories, Challenges, and a Research Agenda for Environmental Politics' (2021) 30 Environmental Politics 119; D Celermajer, S Chatterjee, A Cochrane, S Fishel, A Neimanis, A O’Brien, S Reid, K Srinivasan, D Schlosberg and A Waldow, 'Justice through a Multispecies Lens' (2020) 19 Contemporary Political Theory 475.

4. See D Celermajer, The Sins of the Nation and the Ritual of Apologies (Cambridge University Press 2009).

5. The term comes from K Goodpaster, 'On Being Morally Considerable' (1978) 75 Journal of Philosophy 308. We choose this term rather than the more specific person before the law so as not to constrain ourselves at the outset to the commitments that the model of the person might entail. 
article, we consider some of the principal debates that bear upon transitional justice for the more-than-human and the concerns that have been raised regarding the cogency of this endeavour. In particular, we take up the question of who or what can be morally considerable and the further question of who or what might enter into the processes involved in transitional justice. Reflecting on these debates and concerns, we then articulate a foundational agenda for transitional justice and set out a conceptual framework that we suggest is most suited to working beyond the human. In the fourth part of the article, we turn to soil and to the question of how to approach the business of transforming relations that are not only systemically violent, but that fail to acknowledge soil as the type of community to which justice might be owed. In the conclusion, we briefly consider a collaboration between regenerative farmers and visual artists and explore how their engagements with the arts of relating to the more-than-human might move the as yet private transformations of relations with soil into a more public, albeit incipient, process of justice.

\section{THE CONSTITUTIVE WORK OF ACTS OF JUSTICE}

With Cover's bridge in mind, one might locate 'acts of justice', such as court decisions, prosecutions and punishment, compensation, and symbolic forms of reparation along a scale that traverses the space between the pole where law reflects current reality, and the pole where it instantiates imagined alternatives. These acts might be doing the work of expressing broadly accepted standards of justice, those that embody existing agreements and so reflect the present constellation of power; or they may be doing the work of constituting new standards, those that reflect emerging agreements which are forged as different perspectives and interests rise in prominence and the constellation of power shifts.

To exemplify the former, consider a court finding that an individual is guilty of wilfully killing another person (where this does not take place in a sanctioned context such as war). The facts of the case might be under dispute, but the punishment meted out is unequivocally understood as an expression of the uncontested principle that killing another human is unjust. To exemplify the latter, consider a report by the UN Committee Against Torture indicating that violence against women in the private sphere constitutes a dereliction of the state's duty to prevent torture. ${ }^{6}$ In articulating its authoritative interpretation, the Committee's act is constitutive of a new standard of justice because hitherto the category of torture had been confined to deeds committed by people acting in their public capacity as agents of the state. In this regard, advocacy for the legal recognition of certain categories of action as unjust (and not merely for the recognition of the injustice of specific instances of an accepted category) can be understood as an attempt to convince authoritative bodies (at the state and supra-state level) to act in this constitutive manner. That said, especially in contexts where people

6. See, for example, United Nations Committee Against Torture, 'Concluding Observations on the Fifth Periodic Report of Estonia, adopted by the Committee at its Fiftieth Session (May 6-31, 2013)', where the Committee urged Estonia to adopt comprehensive legislation on violence against women, including domestic violence and marital rape, and to establish effective complaint mechanisms. For background on the gendered nature of authoritative understandings of torture in international law see A Byrnes, 'The Convention Against Torture' in KD Askin and DM Koenig (eds), Women and International Human Rights Law, vol. 2 (Transnational Publishers Incorporated 2000). 
disagree about fundamental norms, many acts of justice will fall somewhere between these poles, and people will disagree about whether the norm those acts express ought to be an accepted standard of justice.

In the field of transitional justice, acts of justice, particularly forms of symbolic reparation, are best understood as being constitutive, not simply of particular standards of justice, but of the basic norms bearing upon matters such as the standing and status of certain groups or identities and hence of the boundaries and contours of the ethical, legal and political community, and the appropriate or acceptable forms of conduct within the community. In this regard, such acts of justice operate at the boundary between the corpus juris and the background myths, narratives, or imaginaries. $^{7}$ To illustrate, take the example of political apologies for wrongs committed by the state, such as the Australian or Canadian apologies for the forced removal of Indigenous children from their families. The acts of apology did not simply register what everyone knew and accepted; they authoritatively constituted the practice of removal as being unambiguously wrong within this political community now and into the future. ${ }^{8}$ To analogize the distinction that JL Austin drew with respect to language, such acts are not constative but performative. ${ }^{9}$ They seek to bring something into existence and, it should be added, to move something out of existence.

A further implication of this constitutive character of transitional justice is that its temporality is neither linear nor straightforwardly progressive, but rather multidirectional and faltering. From a formal and positivist perspective, it would usually be the case that the explicit acts of wrongdoing that are the object of the reparative act (say the apology) belong to the past. However, the norms, the imaginaries and the epistemic logics - or in Cover's terms, the myths and narratives - that legitimated those wrongs persist. As one clearly sees in the case of the relationship between postcolonial states and Indigenous peoples, these 'wrongful myths, narratives and logics' continue to sustain other forms of wrongdoing such as police violence. ${ }^{10}$ The apology for one class of wrongful action that those myths and narratives authorized contributes towards invalidating those very myths and narratives, but is unlikely to completely dispel them. This means that transitional justice mechanisms can be deployed, and indeed must be capable of being deployed, in contexts where violence or wrongdoing flowing from those myths and narratives persists.

7. Imaginaries, as we understand them, constitute our shared background, and it is through an imaginary that we experience ourselves and the world and form both our expectations and our projects. See C Taylor, Modern Social Imaginaries (Duke University Press 2004) 23. Following Lennon, imaginaries have affective and normative force. See K Lennon, Imagination and the Imaginary (Routledge 2015) 73.

8. Celermajer, The Sins of the Nation (n 4). Note authoritatively does not mean definitively or universally. Contestation persists.

9. JL Austin, How to Do Things with Words (Oxford University Press 1975).

10. C Cunneen, 'Colonial Processes, Indigenous Peoples, and Criminal Justice Systems' in S Bucerius and M Tonry (eds), The Oxford Handbook of Ethnicity, Crime, and Immigration (Oxford University Press 2014) 386. A powerful illustration of the layers of coloniality is illustrated by the fact that while the Royal Commission into Aboriginal Deaths in Custody in Australia documented in detail how the legacy of colonialism and ongoing colonial institutions infused all aspects of the criminal justice system, the Commission itself can be seen as a colonizing institution. See E Marchetti, 'The Deep Colonizing Practices of the Australian Royal Commission into Aboriginal Deaths in Custody' 2006 33(3) Journal of Law and Society 451-74. 
The fact that transitional justice works in this constitutive mode, and that it is amenable to contexts of ongoing wrongdoing is critical when considering its applicability to the more-than-human, at least if the analysis is to speak to actual conditions and to lay a path for a realistic course of action, rather than setting out speculative ideals. ${ }^{11}$ There can be no illusion that the systemic violence against animals and the environment is anywhere near its end. Indeed, if transitional justice is to have any purchase as a form of justice for the more-than-human, the constitutive dimension of transitional mechanisms will inevitably be radically amplified.

To illustrate, compare the deployment of transitional justice mechanisms during periods of political transition in the wake of a history of systemic racism with their hypothetical deployment in relation to the large-scale killing and abuse of animals in industrial farming. In the case of racism, the objective of the mechanisms such as political apologies, reparation schemes or Truth and Reconciliation Commissions is to instantiate norms of racial equality and respect within the polity. ${ }^{12}$ Admittedly, it may be that majorities and stakeholders with institutional power continue to reject such norms and that racial discrimination and violence persist, but the condemnation of racist norms and acts has nevertheless been advocated by a significant (albeit previously marginalized) portion of the polity, and is well instantiated in supra-national standards such as international human rights law. ${ }^{13}$ In the case of animal slaughter, the objective of our hypothetical transitional mechanisms would be (amongst others) to instantiate norms concerning animals' rights to life and to be free from torture. In this case, although a small minority of humans support these norms, they are virtually comprehensively rejected across the larger community, and their systemic violation is economically, socially, legally and politically institutionalized within the polity. ${ }^{14}$ Nor can these norms find affirmation in international law, not even in international law that is routinely flouted. Whereas in the first case, at least certain forms of racialized violence will have been curtailed when transitional justice mechanisms are deployed, the acts being called into question in relation to the more-than-human persist and are likely to endure for the foreseeable future.

Adopting Cover's frame illuminates how transitional justice's character as justice in its constitutive dimension should not be seen as a weakness, as if it were a second best to the more established and constative dimensions of justice - the distributive, retributive

11. Our point is not to disparage abstract ideals of speculative theory but to clarify our approach.

12. See, for example, A Valls, 'Racial Justice as Transitional Justice' (2003) 36(1) Polity 53-71 and Celermajer, The Sins of the Nation (n 4). For a critical view with respect to apologies to Indigenous peoples, see J Corntassel and C Holder, 'Who's Sorry Now? Government Apologies, Truth Commissions, and Indigenous Self-Determination in Australia, Canada, Guatemala, and Peru' (2008) 9(4) Human Rights Review 465-89.

13. For example, in making its findings in relation to the forced removal of Aboriginal and Torres Strait Islander children, the Australian Human Rights Commission made reference to a number of international human rights standards, including the Convention on the Elimination of All Forms of Racial Discrimination and the Convention on the Prevention and Punishment of the Crime of Genocide. See Australian Human Rights and Equal Opportunity Commission, Bringing Them Home: Report of the National Inquiry into the Separation of Aboriginal and Torres Strait Islander Children from their Families (Sydney HREOC 1997), especially Chapter 13.

14. D Wadiwel, The War Against Animals (Brill 2015). 
or compensatory. As Juan E Corradi put it in one of the earliest uses of the term, transitional justice is more than ordinary justice, 'because it aims beyond the simple ordering of human relations: it seeks to achieve moral and political regeneration' ${ }^{15}$ Especially in the context of the fragility and incipient nature of norms concerning wrongs against beings other than humans, and in the light of current realities, it is in its transitional mode that justice can do its most important and transformative work. At a later moment, other dimensions of justice might have their time. Nevertheless, for transitional justice to do its transformative work, it too needs to be critically scrutinized and cleansed of its anthropomorphism and of the assumptions that it encodes about the nature of the subject of (in)justice.

\section{TOWARDS A CONCEPTUAL FRAMEWORK FOR TRANSITIONAL JUSTICE AND THE MORE-THAN-HUMAN}

Our discussion so far has rested on two highly inclusive terms: transitional justice and the more-than-human. At the outset of this discussion, we continue to use these two terms without further specification so as to canvas some of the debates that have taken place at their interface. As the discussion proceeds, we will narrow in on each.

Broadly understood, transitional justice is concerned with the question of how to effect a social and political transformation from a political community whose past has been characterized by various forms of systemic violence, injustice and (in the human realm) violations of human rights, to one whose future is premised on and capable of sustaining just relations and social peace. ${ }^{16}$ As transitional justice developed as a field of practice, various mechanisms came to be thought of as a type of 'toolkit' for transition: trials, truth or truth and reconciliation commissions, restitution and compensation, various forms of institutional reform, apology, memorials and a range of forms of symbolic reparation. The aims of transitional justice are generally framed in terms of their double temporality, being backward looking (accountability for wrongdoing in the past) and forward looking (establishing the normative and institutional conditions for sustainable peace and justice).

What is distinctive about transitional justice is, however, somewhat lost if it is conceptualized purely in terms of what the particular mechanisms might deliver: for example, accountability for wrongdoing, or compensation and restitution to enable victims to move forward in ways that the harms they suffered had impeded. Rather, these dimensions of accountability and reparation are folded into the larger aim of transforming the relationships that constitute the social order, ${ }^{17}$ or in the terms we

15. JE Corradi, 'Toward Societies Without Fear' in JE Corradi and others (eds), Fear at the Edge: State Terror and Resistance in Latin America (University of California Press 1992) at 267. Notably, this excerpt is taken from a larger passage where Corradi was arguing that transitional justice is both more and less than ordinary justice. The reasons for its being less are principally concerned with the power dynamics of political transitions.

16. For overviews see M Minow, Between Vengeance and Forgiveness: Facing History after Genocide and Mass Violence (Beacon Press 1998); RG Teitel, Transitional Justice (Oxford University Press 2000); P Arthur, 'How Transitions Reshaped Human Rights: A Conceptual History of Transitional Justice' (2009) 31 Hum Rts Q 32.

17. That the form of relationships gives shape to the social order is perhaps best explained by the notion of the field. As Cassirer wrote, 'The field itself can no longer be understood as a 
established at the outset of this article: transforming the myths, narratives and social imaginaries of the polity.

The centrality of relational transformation is illuminated in a slightly different characterization of transitional justice as a technology of moral repair, an approach articulated perhaps most clearly in the work of Margaret Urban Walker. ${ }^{18}$ The moral repair approach does not reject the backwards-forwards temporality of transitional justice, nor suggest different mechanisms, but rather seeks to centre the work of transforming the relationship between the parties (individuals and collectives) who have been variously perpetrators, victims, beneficiaries and bystanders. ${ }^{19}$ Consistent with Hannah Arendt's understanding of forgiveness as that form of action that makes possible a future that is not mere reaction to the past but allows for the authentically new to arise ${ }^{20}$ reorganizing relational dynamics is here understood to be the fundamental driver of the ultimate social and political transformation, albeit allowing that different actions might be most effective in bringing about this shift. ${ }^{21}$ So, for example, whereas in the abstract, compensation might seem to do the work of enabling victims to pursue opportunities that had been curtailed by the wrongs committed against them and to live lives that had been damaged, contextualized within the overall framework of moral repair, compensation is expressive of a recognition that the prior relationship had been organized in a harmful and asymmetrical way and that (from an ethical point of view) it needs to be recalibrated.

Although, in practice, the field of transitional justice has been entirely focused on wrongs between humans, some have suggested that its three linked goals - providing accountability for the past, laying the foundation for a just future and repairing relationships - might be usefully brought to attend to the wrongs that humans have committed against the more-than-human world. ${ }^{22}$ For the most part theoretical speculations have not explicitly assumed the frame of transitional justice, with the notable exception of Charlotte Blattner's comprehensive analysis of how transitional mechanisms might be brought to bear on interspecies relations, focusing on humans and animals other than humans. ${ }^{23}$

merely additive whole, as an aggregate of parts. The field is not a thing-concept but a relationconcept; it is not composed of pieces but is a system, a totality of lines of force'. E Cassirer, The Logic of the Cultural Sciences (Yale University Press 2000) 92.

18. MU Walker, Moral Repair: Reconstructing Moral Relations after Wrongdoing (Cambridge University Press 2006).

19. In this vein, although not including beneficiaries and bystanders, Minow writes: 'Building connections and enhancing communication between perpetrators and those they victimized, and forging ties across the community, take precedence over punishment or law enforcement.' Minow (n 16) 91-2. See also D Van Ness and KH Strong, Restoring Justice (Office of Justice Programs 1997).

20. H Arendt, The Human Condition (University of Chicago Press 2013) 237.

21. Walker (n 18).

22. Paul Taylor's Respect for Nature is frequently cited as the foundational text for suggesting that restitution ought to be done in relation to harms committed to beings other than humans, although he did not use the language of transitional justice and indeed has been strongly criticized in animal and environmental justice literatures for positing an understanding of restitution that enables ongoing abuse. See PW Taylor, Respect for Nature (Princeton University Press 1986). The most comprehensive treatment of traditional justice for animals we are aware of is Blattner (n 1).

23. Blattner (n 1). 
In contemplating this shift from intra-human to human-more-than-human injustice, a number of objections have been raised. ${ }^{24}$ Here, we focus on a family of objections which worry that beings other than humans do not have the requisite capacities to be parties to transitional justice. In its more basic form, the objection is that beings other than humans cannot be subjects of justice per se because they cannot be harmed in morally relevant ways. ${ }^{25}$ The more onerous form of the objection is that even if the moral considerability of beings other than humans is recognized, they lack the capacities required for the distinctive type of relational transformation that lies at the heart of transitional justice. ${ }^{26}$ Interrogating these objections will allow us to elaborate our own approach to transitional justice for the more-than-human.

For the purposes of this discussion, we deal quite briefly with the first form of the objection, not least because of the extensiveness of the debate concerning the moral considerability of the many types of beings who fall into the broad category of the more-than-human. Such debates range from classical claims about animals' sentience and their being subjects of their own lives, and hence having moral claims or rights, ${ }^{27}$ through more complex questions concerning how to justify the moral considerability of lifeforms such as ecosystems or species, which cannot in any straightforward way be brought under the categories of sentient subjects or subjects of a life.$^{28}$ For the purposes of this discussion, we propose accepting the proposition that there are sound cases for claiming that a broad range of lifeforms other than humans - including

24. Our intention is not to provide a comprehensive inventory of objections, but to focus on those that motivate our position. For example, we do not consider the objection that restorative or reparative approaches implicitly enable ongoing abuse, an objection taken up in relation to animals in KS Emmerman, 'Sanctuary, Not Remedy: The Problem of Captivity and the Need for Moral Repair' in L Gruen (ed), The Ethics of Captivity (Oxford University Press 2014) and in relation to the environment in E Katz, Nature as Subject: Human Obligation and Natural Community (Rowman \& Littlefield 1997). Nor do we consider the so-called baseline problem that queries which state of nature ought to be sought in restoration, as argued in M Oksanen, 'Ecological Restoration as Moral Reparation' (2008) 23 Proceedings of the XXII World Congress of Philosophy 99, and the related 'erroneous replacement' problem, which suggests that all restoration involves replacing what has been destroyed with a fake, as argued in R Elliott, Faking Nature: The Ethics of Environmental Restoration (Routledge 1997).

25. For a discussion of the Cartesian foundation of the exclusion of beings other than humans from the circle of moral subjects, see GL Francione, Animals as Persons: Essays on the Abolition of Animal Exploitation (Columbia University Press 2008).

26. For example, C Palmer, Animal Ethics in Context (Columbia University Press 2010). For a more extensive discussion of these and a range of other objections, see Blattner (n 1).

27. The classical statements on sentience as the basis for moral considerability is P Singer, Animal Liberation (Harper Collins 1975) and on being a subject of a life is T Regan, The Case for Animal Rights (University of California Press 2004). For an ecofeminist position see V Plumwood, Feminism and the Mastery of Nature (Routledge 1993).

28. An important line of development here has been the application of a capabilities approach, whereby harm is understood as an interruption in functioning. On the application of capabilities approaches to the environment see D Schlosberg, Defining Environmental Justice: Theories, Movements, and Nature (Oxford University Press 2007). On the argument for the application to ecosystems and species, see K Norlock, 'The Atrocity Paradigm Applied to Environmental Evils' (2004) 9 Ethics and the Environment 85. Claudia Card's application of this approach in C Card, The Atrocity Paradigm: A Theory of Evil (Oxford University Press 2002) has been taken up by scholars arguing for transitional justice approaches for animals, notably G Scotton, 'Interspecies Atrocities and the Politics of Memory' in A Woodhall and G Garmendia da Trindade (eds), Political Approaches to Nonhuman Animal Issues (Palgrave Macmillan 2017). 
not only animals and trees, but also ecosystems, rivers and soils - can be harmed in morally relevant ways. Because, however, those cases, in some instances far more than others, are not broadly accepted, any approach to transitional justice will need to deal from the outset with the most basic constitutive dimensions of justice: that the lifeform in question is the type of being or beings or community that can be wronged in morally relevant ways, that humans' actions vis-à-vis those lifeforms constitute wrongs, and hence that humans have committed injustices against those beings.

The work of bringing polities to recognize certain acts as moral wrongs is by no means foreign to transitional justice in the intra-human realm, as we see with particular poignancy in the case of wrongs against Indigenous peoples. To return to our example of the Australian debate about an apology for the forced removal of Indigenous children from their families, the resistance to a national apology was driven to a significant extent by the insistence that the practice had been for the children's own good. ${ }^{29}$ Similarly, the practice that has been adopted by various organizations in recent years of acknowledging that a meeting is taking place on unceded Indigenous land occurs within a context where neither legally nor socially are Indigenous land rights and the wrongful theft of Indigenous land broadly accepted. Those speech acts are performative in the sense that they are constitutive narratives in which the characters occupying the roles of perpetrator and victim of injustice are being recast.

Judith Butler was pointing to a similar failure to recognize certain people as subjects of justice when she drew a connection between the absence of mourning or grief over the killing of certain people, specifically those from countries with which the USA was at war, and the constitutional discounting of those lives. ${ }^{30}$ Drawing on Butler's ideas, a number of scholars, including Chloe Taylor and James Stenescu, have explicitly connected the need to confront and challenge the widespread failure to recognize the moral significance of harm done to animals by using mourning and memorialization - key aspects of the toolkit of transitional justice. ${ }^{31}$ Similarly, drawing on the literature on the mechanisms for denial, ${ }^{32}$ Guy Scotton has argued that in a context where certain lives (in this case animal lives) are not accorded moral considerability, rituals and performances of mourning and memorialization can perform a constitutive function. ${ }^{33}$ We refer to this work not to suggest that mourning and memorialization will always be the most appropriate transitional justice mechanisms to do the work of constituting certain beings as morally considerable,

29. For a detailed discussion see Celermajer The Sins of the Nation (n 4).

30. J Butler, Frames of War: When is Life Grievable? (Verso Books 2009). To link this back with the removal of Indigenous children, in parliamentary debates in Western Australia in 1904, JM Drew said, '[A] half-caste, who possesses few of the virtues and nearly all of the vices of whites, grows up to be a mischievous and very immoral subject ... it may appear to be a cruel thing to tear an Aborigine child from its mother, but it is necessary in some cases to be cruel to be kind.' Quoted in P Biskup, Not Slaves, Not Citizens: The Aboriginal Problem in Western Australia 1898-1954 (University of Queensland Press 1973) 142.

31. J Stanescu, 'Species Trouble: Judith Butler, Mourning, and the Precarious Lives of Animals' (2012) 27 Hypatia 567; C Taylor, 'The Precarious Lives of Animals: Butler, Coetzee, and Animal Ethics' (2008) 52 Philosophy Today 60.

32. The classic text is S Cohen, States of Denial: Knowing about Atrocities and Suffering (John Wiley \& Sons 2013). In the area of environmental harm and climate change specifically see KM Norgaard, Living in Denial: Climate Change, Emotions, and Everyday Life (MIT Press 2011).

33. Scotton (n 28). 
but rather to indicate how others have thought about this connection. When we turn to harms against soil in the next part of the article, we will outline the case for recognizing that soil can be (and has been) harmed in morally considerable ways, and will trace some of the practices that are building recognition of soil's moral status.

Let us turn then to the more onerous objection and the one more specific to transitional justice per se. Even if it is accepted that beings radically different to humans can be harmed in a morally relevant sense, the objection remains that transitional approaches require not merely a subjective point of view, but more demandingly, a reflexive relationship with that harm: the subject must be aware of the harm as harm. As discussed below, it is thus contended, first, that transitional justice requires that those who participate in it should have quite demanding reflexive capacities or affordances, and, second, that beings other than humans do not (for the most part, if not entirely) have them. These putatively requisite capacities fall into two categories. First are those capacities or affordances required in order to experience harm as a moral wrong or as an injustice in a way that would make transitional approaches relevant or meaningful for the participant being/s. Second are the capacities and affordances required to participate in or to benefit from the transformative processes that transitional mechanisms seek to achieve: to have an experience whereby the awareness of harm as harm is replaced by an awareness of transcending or transforming that harm, not necessarily into an experience of justice, but into something akin to reconciliation or moral healing. ${ }^{34}$

Thus, for example, falling within the first category, Clare Palmer argues that animals 'lack concepts of justice, bear no grudges against either perpetrators or beneficiaries, and seek no satisfaction from either'. ${ }^{35}$ In a similar vein, Donaldson and Kymlicka argue that 'most animal communities do not retain detailed intergenerational records of abusive treatment by humans'. ${ }^{36}$ Palmer also thinks that animals lack the second set of capacities, arguing that they are incapable of obtaining satisfaction, as humans can, when they see that reparative action is taken in relation to harms they have suffered. ${ }^{37}$

Similar objections are raised with respect to the environment. Oksanen writes for example that nature cannot count as a victim in the morally relevant sense because it lacks 'the essential psychological and complex qualities that characterize the life and the experiences of human victims and the nature of human communality'. ${ }^{38}$ Detecting a similar absence of a subject that one could meaningfully call the morally relevant victim, Katz also rejects the cogency of a reparative stance vis-à-vis nature. ${ }^{39}$ In response to Almassi's claim that one can imagine reparative processes that would

34. Walker's writings certainly can be seen to give rise to this understanding. She writes, for example that moral repair 'involves the restoration or construction of confidence, trust, and hope in the reality of shared moral standards and of our reliability in meeting and enforcing them'. MU Walker, 'Moral Repair and its Limits' in TF Davis and K Womack (eds), Mapping the Ethical Turn (University of Virginia Press 2001) 120.

35. Palmer (n 26) 104. This is not a reason in Palmer's view not to take action that will alter the conditions to prevent future harms, but that the language of reparations ought not be used.

36. S Donaldson and W Kymlicka, Zoopolis (Oxford University Press 2016) 258.

37. C Palmer, 'Can We - and Should We - Make Reparation to "Nature"?' in WP Kabasenche, M O'Rourke and MH Slater (eds), The Environment (MIT Press 2012).

38. Oksanen (n 24).

39. E Katz, 'Replacement and Irreversibility: The Problem with Ecological Restoration as Moral Repair' (2018) 23 Ethics and the Environment 17. 
rebuild trust between nature and humans, ${ }^{40}$ Katz suggests that even if this is a metaphor, it is one 'strained beyond coherence'. ${ }^{41}$

A number of responses attempt to resist these objections. One is to call into question the assumption that the beings in question do not have the requisite capacities. In her comprehensive treatment of transitional justice for animals other than humans, Blattner takes this approach, mustering ethological research on animals' memories, awareness of death, experience of trauma, and capacity for reconciliation and forgiveness, as well as cautioning against projecting our assumptions into fields of knowledge about which we remain largely ignorant and have been shown to approach with dogmatic commitments. ${ }^{42}$ As formulated, this response would still seem to limit the class of beings who might be involved, but Indigenous ontologies $^{43}$ or new animisms would suggest much more complex capacities for the whole of nature. ${ }^{44} \mathrm{~A}$ second move is to argue that even if the ecological communities or beings who are the explicit object of harm (say, soils or rivers) lack the relevant capacities, these direct harms result in more indirect harms to others who do have the required capacities (including people). ${ }^{45}$

A third response is to move the focus away from the victim altogether and to argue that the object of the reparative acts is the transformation of the perpetrators. On this account, one need ask nothing of the victim, because what matters is that, by virtue of their involvement in reparative acts, those who habitually cause harm come to recognize their wrongs, and, through this moral encounter, become different types of people; people who would not commit such acts. ${ }^{46}$

A fourth and far more radical response from an ontological point of view is to move from focusing on the victim or on perpetrator to focusing on the relationship. Almassi gives the example of a fish restoration project in the Great Lakes region led by the Little River Band of Ottawa Indians, an Anishinaabe nation. ${ }^{47}$ Describing the project, Holtgren, Ogren and Whyte write, 'The fish has been able to both heal old wounds and create new, sustainable relationships among people, even in a watershed

40. B Almassi, 'Ecological Restorations as Practices of Moral Repair' (2017) 22 Ethics and the Environment 19, at 24.

41. Katz (n 39) 21.

42. Blattner (n 1), see $35 f f$.

43. A Poelina, 'A Coalition of Hope! A Regional Governance Approach to Indigenous Australian Cultural Wellbeing' in A Campbell, M Duffy and B Edmondson (eds), Located Research (Springer 2020); RW Kimmerer, 'Learning the Grammar of Animacy 1' (2017) 28 Anthropology of Consciousness 128.

44. G Harvey, Animism: Respecting the Living World (Columbia University Press 2005); F Mathews, For Love of Matter (State University of New York Press 2003).

45. Card (n 28) makes this argument in relation to ecosystems and those who depend or live within them.

46. J Basl, 'Restitutive Restoration: New Motivations for Ecological Restoration' (2010) 32 Environmental Ethics 135; TE Hill, 'Ideals of Human Excellence and Preserving Natural Environments' (1983) 5 Environmental Ethics 211; W Throop, 'Environmental Virtues and the Aims of Restoration' in A Thompson and J Bendik-Keymer (eds), Ethical Adaptation to Climate Change: Human Virtues of the Future (2012). Smith objects that this focus on the perpetrator problematically marginalizes the good of the victim, but this seems to us to overlook the effect of transforming the perpetrator on the victim. See L Smith, 'On the "Emotionality" of Environmental Restoration: Narratives of Guilt, Restitution, Redemption and Hope' (2014) 17 Ethics, Policy \& Environment 286.

47. Almassi (n 40). 
where these relationships have been strained by settler colonialism' ${ }^{48}$ The radicality of this response lies in the ontological shift from subjects being the primary site of being, and then forming different types of relationships, to the relationship being the fundamental ontological unit. No particular capacities or affordances are required of distinct parties, because they (and their capacities and affordances) come into being only and always in relationship.

In reflecting on these objections and the various attempts to parse them, we can see that, except in the last case, there is a tendency to retain an ontological schema in which ideas (or reflexivity understood as residing in the realm of ideas) are valorised as the sole site of meaning-making and hence also of freedom. Thus, both the sense of harm as harm and the capacity to be engaged in transformation are assumed to take place in the realm of ideas and cognitive understanding (I know that I have been harmed and I understand that you are sorry). Transitional interventions effect moral repair, on this view, by transforming people's ideas and understandings about the principles or substantive demands of justice, about different identities and so on. To the extent that this emphasis on ideas remains tied to persistent ontological hierarchies - articulated from Plato through to representations of the great Chain of Being, to Descartes, to Kant and into contemporary humanisms that emphasize the capacity for complex linguistic moves - other beings are bound to fall short. Indeed, as Adorno wrote,

Animals play for the idealist system virtually the same role as the Jews for fascism. To revile man as an animal - that is genuine idealism. To deny the possibility of salvation for animals absolutely and at any price is the inviolable boundary of its metaphysics. ${ }^{49}$

What, though, if we allow that both recognition of wrong as wrong and moral transformation can also occur through shifting embodied encounters and material relationships? Importantly, and consistent with a range of ontological positions such as Merleau Ponty's body-oriented phenomenology, new materialism and Actor Network Theory, this shift from 'ideas' to 'material' should not be taken to be coincident with the shift from a meaning-laden realm in which agency and freedom reside and reflexivity takes place, to a second, brute realm devoid of meaning except for that which the first bestows upon it. ${ }^{50}$ To return to Cover, myths 'build relations between the normative and the material universe' ${ }^{51}$ To be clear, in adopting this ontological position we are not arguing that this move is a requirement of transitional justice for the more-than-human because the beings concerned lack language or reflexivity and hence are in deficit. Indeed, although the self-understanding of transitional justice in

48. M Holtgren, S Ogren and KP Whyte, 'Renewing Relatives: One Tribe's Efforts to Bring Back an Ancient Fish' (2015) Earth Island Journal 30(3). Available at <http://www.earthisland. org/journal/index.php/eij/article/renewing_relatives/>, quoted in Almassi (n 40) at 22.

49. TW Adorno, Beethoven: The Philosophy of Music, trans. E. Jephcott (Stanford University Press 1998) 80.

50. The three large bodies of theory noted here, Merleau Ponty's phenomenology, new materialism and Actor Network Theory (ANT) are by no means the same, but all three reject an ontology in which meaning (and the associated qualities of freedom, agency and so on) is invested only on one side of a fundamental dualism. See M Merleau-Ponty, Phenomenology of Perception (Routledge 1962); D Coole and S Frost, New Materialisms: Ontology, Agency, and Politics (Duke University Press 2010); and B Latour, 'Networks, Societies, Spheres: Reflections of an Actor-Network Theorist' (2011) 5 International Journal of Communication 15.

51. Cover (n 1). 
the human realm has underplayed the role of embodied transformation and has largely seen shifts in material relationships as being representative of the primary 'normative' shift, we would reject this dualistic understanding. ${ }^{52}$ Nevertheless, when we move to the question of relationships between humans and beings who either do not, or may not, have a form of consciousness or modes of communication that resemble that of humans, the emphasis on a presumed realm of reflexive ideas is neither sustainable nor, more importantly, ethically appropriate.

Thus, transitional justice for the more-than-human must be premised on an ecocentric and posthumanist framework. Grounding transitional justice in this way entails rejecting the automatic adaptation or extension of approaches that were developed solely with humans in mind when it comes to developing transitional justice for systemic wrongs against the more-than-human. Certainly, as Blattner cogently argues, the default assumption that animals (in the case she is analysing) lack the requisite affordances also needs to be met with significant scepticism. ${ }^{53}$ From an ethical point of view, however, extensionist approaches impose logics within which morethan-human beings are from the outset encoded according to their proximity to or distance from the ideal of the human subject, within a hierarchical ordering in which they are doomed to be deficient. Indeed, if transitional justice for the more-than-human is to deal with the failure to recognize that morally relevant wrongs have been committed at all, then, as a field, transitional justice must also come to terms with the 'ur-problem' of the implicit equation of distinctly human affordances, not only with moral considerability but with the capacity to experience injustice and transformation.

Others have made a similar move in cognate fields. Considering what political deliberation involving animals might look like, for example, Donaldson and Kymlicka consider the practices undertaken at VINE Sanctuary, where animals gather when decisions are made. Although they 'cannot articulate their views in discussion, ... they are a presence, a reminder, and a check, on human deliberation' ${ }^{54}$ Going further, Donovan Schaefer argues that rather than starting with our conception of the human practice of religion as essentially ideational, belonging to a realm called 'spirit' as distinct from body, to allow the possibility of animal religion entails starting with animals' embodied experience of and resonance with the world they encounter. ${ }^{55}$ Drawing on the material turn in religion, he quotes Vásquez' demand that we recognize 'that, although our experience of the world is mediated through our discursive

52. See D Celermajer, 'Mere Ritual? Displacing the Myth of Sincerity in Transitional Rituals' (2013) 7 International Journal of Transitional Justice 286.

53. Blattner (n 1).

54. S Donaldson and W Kymlicka, 'Farmed Animal Sanctuaries: The Heart of the Movement' (2015) 1 Politics and Animals 50, at 67. Isabelle Stengers makes a related argument about presence when she writes, 'We know that in laboratories in which experiments are performed on animals, all sorts of rites and ways of talking and referring to those animals exist, that attest to the researchers' need to protect themselves. ... The correlate of the necessity of "deciding" on the legitimacy of an experiment would then be the invention of constraints directed against these protective manoeuvres, forcing the researchers concerned to expose themselves, to decide "in the presence of" those that may turn out to be the victims of their decision'. I Stengers, 'The Cosmopolitical Proposal' in B Latour and P Weibel (eds), Making Things Public: Atmospheres of Democracy (MIT Press 2005) 994, at 997.

55. DO Schaefer, Religious Affects: Animality, Evolution, and Power (Duke University Press 2015). 
and nondiscursive practices, we cannot reduce to human texts the materiality of our bodies and the world in which and through which we live'. ${ }^{56}$

In a similar vein, if transitional justice is to be brought into the sphere of relations between humans and the more-than-human world, its modalities must be adapted to the ways of being of those involved and not only the ways of being, knowing and transforming that humans occupy and narrate. In this regard, what remains of transitional justice is the search for acts that can catalyse transformation in relations that have been damaged. What falls away is the assumption that such acts must be meaningful in the ways that humans believe meaning-making occurs. The myths and narratives underpinning transitional justice itself must also be subject to transformation.

\section{PRACTICES OF SOIL JUSTICE}

As foreshadowed earlier, to explore how transitional justice might be taken up in relation to wrongs against beings other than humans, we focus here on soil. Even as beings such as animals and trees begin to show up as forms of life that might merit moral considerability, soil largely remains imagined as a lifeless substance or medium, a resource, and as such, an entity whose well-being matters only in so far as it effects the well-being of others.

For most human societies (with the exception of some Indigenous societies), ${ }^{57}$ violence to soil is an everyday and unremarkable occurrence, just as soil itself is commonly considered a backdrop to more important things. Among societies practising industrial agriculture, violence to soil is normalized and even celebrated, with tilling widely lauded as a civilizational achievement. Where soil is harmed, the harm and its effects tend to appear slowly (if at all), more commonly through absence rather than presence. This challenges most humans' perceptive capacities, which more easily attune to the charismatic creatures that show emotion through more immediate facial and bodily expressions. Rob Nixon's concept of 'slow violence' is illuminating here. Slow violence is 'a violence that occurs gradually and out of sight, a violence of delayed destruction that is dispersed across time and space, an attritional violence that is typically not viewed as violence at all' ${ }^{58}$ As Nixon highlights, such violence does not bear the same phenomenal qualities or event forms of more compressed and dramatic

56. MA Vásquez More than Belief: A Materialist Theory of Religion (Oxford University Press 2011) 321, quoted in DO Schaefer, 'Do Animals Have Religion? Interdisciplinary Perspectives on Religion and Embodiment' (2012) 25 Anthrozoös 173.

57. There is evidence that some forms of tilling and other techniques of soil modification practised by Indigenous farmers and hunter gatherers cause significantly less erosion than conventional mechanized (mouldboard) ploughing. For example, G Rajaram et al. argue that the conservation tillage systems developed in the West have many characteristics of Indigenous tillage systems. They show this by highlighting examples of Indigenous tillage systems in India and the United States. See G Rajaram, DC Erbach and DM Warren 'The Role of Indigenous Tillage Systems in Sustainable Food Production' (1991) 8(1-2) Agriculture and Human Values 149-55. Analysis of fluvial sediments in South Eastern Australia by Portenga et al. shows that soil erosion rates from low-intensity, high-frequency Aboriginal burning regimes in the late Holocene were equal to background erosion rates from natural causes. See EW Portenga, DH Rood, P Bishop and PR Bierman, 'A Late Holocene Onset of Aboriginal Burning in Southeastern Australia' (2016) 44(2) Geology 131-4.

58. R Nixon, Slow Violence and the Environmentalism of the Poor (Harvard University Press 2011) 2 . 
types of violence, and is thus is less amenable to spectacle or to sparking moral concern. ${ }^{59}$ Nixon observes that slow violence 'typically occurs in the passive voice without clearly articulated agency'. ${ }^{60}$ Often this is also because the actions that constitute such violence are embedded within much larger structural frameworks of action that have long been taken for granted, as inevitable parts of life.

Violence to soil involves damage to soil ecological and physical integrity, and thus its flourishing and ability to support biodiversity. ${ }^{61}$ Soil typically harbours a staggering diversity of other lifeforms - species from all evolutionary domains bacteria, archaea and eukarya - and accordingly, is vulnerable to myriad harms. ${ }^{62}$ As ecological communities, relationships between species in soils develop over time, manifesting emergent properties, some of which can be understood as ecological functions. Violence to soil commonly involves high levels of disturbance: for example, ploughs that invert topsoil and compact the soil profile, or building impervious surfaces, such as roads, which also cause compaction. These actions sever soil's connectivity, collapsing pores and destroying fungal vessels that connect to plant roots and feed the soil food web. Exposed to the elements, vulnerable soil structures (micro and macro aggregates) degrade, reducing soil's water-holding capacity and leading to erosion.

Violence to soil is normalized by dominant conceptions of soil as primarily a raw material or a vessel, with value realized in its outputs, rather than soil being understood as something that is intrinsically valuable. In modern times, soil is seen as fungible, due to properties that afford exchange. Activities such as moving soil, buying soil and disposing of soil depend on its ability to be handled in bulk and moved in great volumes. When such perceptions of soil's fungibility are dominant and not tempered by appreciation for soil's less replaceable, living and more relational qualities, attitudes can prevail that amount to disregard for soil's particularity, fragility and needs. ${ }^{63}$ To treat Earth Others solely as tools for use involves a type of violence, dispensing with the kind of ethical respect encoded in Kant's categorical imperative, which requires that we treat others (however, for Kant human others only) not simply as means but also as ends in themselves. ${ }^{64}$ While soil's instrumental value to humans is a dimension of interdependence, recognition of soil's usefulness can crowd out appreciation of its own character and its own being in the world. Overly objectified understandings of soil that render it a passive receptacle of plant growth indifferent to its connectivity being severed, rather than as a living community with capabilities in, within and for itself - can both drive and result from violent practices towards it.

In addition to narrow instrumental conceptions that provide implicit licence for violence towards soil, certain myths and narratives not only permit but celebrate

59. ibid $128-9$.

60. ibid 136.

61. For a discussion of ecological integrity, capabilities and ecological justice, see D Schlosberg, Defining Environmental Justice: Theories, Movements, and Nature (Oxford University Press 2007) 153.

62. M Beare, D Coleman, D Crossley, P Hendrix and E Odum, 'A Hierarchical Approach to Evaluating the Significance of Soil Biodiversity to Biogeochemical Cycling' (1995) 170 Plant and Soil 5-22.

63. M Nussbaum sees fungibility as a key dimension of the objectification of women in her book Sex and Social Justice (Oxford University Press 1999).

64. This formulation of the categorical imperative appears in I Kant, Groundwork for the Metaphysics of Morals (Harper and Rowe 1964). 
such violence. An influential narrative regarding technology is that the development of the plough helped to produce civilization (where civilization is understood as an unambiguously positive development). This narrative is used for two historical periods: the Neolithic revolution and the Green Revolution (mechanization) of modern agriculture. BBC economics journalist Tim Harford brings the two together in a radio series entitled 50 Things That Made the Modern Economy:

Four decades ago, the science historian James Burke ... asked a simple question: Surrounded by the wreckage of modernity, without access to the lifeblood of modern technology, where do you start again? What do you need to keep yourself - and the embers of civilisation - alive? And his answer was a simple yet transformative piece of technology: a plough. And that's appropriate, because it was the plough that kick-started civilisation in the first place, and which - ultimately - made our modern economy possible. ${ }^{65}$

Here, Harford quotes a hyperbolic statement from the 1970s, without regard for the ways in which ploughs have been more critically evaluated in the decades since, particularly by farmers themselves. While there is no question that the plough has 'made' the modern economy in terms of influencing the ways in which the economy has developed (including the modes of exchange between soils and plants), the lifesaving credentials of ploughs - particularly as technologies of choice amid a world in ruin, are dubious. Such triumphalist discourses discourage more frank reflection across society on the harms that ploughs have caused soils and communities of diverse species, humans included, that depend on soils.

Greater ambivalence regarding the impact of ploughs can be found among farmers. A movement towards greater care for soil needs, containing a nascent respect for soil's flourishing (despite an overall instrumental justification for changed practices) has grown in recent decades, involving reduced tillage and increased plant diversity on farms. The adoption of conservation agriculture practices in cropland for example, increased globally by 10.5 million hectares each year between 2008-2009 and 2015-2016, reaching about 12.5 per cent of total cropland. ${ }^{66}$ In Australia and across much of the world, farmers have increasingly adopted practices and technologies that account for the complex nutritional needs, physical structure, chemical sensitivity and biological liveliness of soil, with many beginning to conceive of soil differently: as deserving of care. ${ }^{67}$

No-till or low-till farming techniques involve the use of modified machinery for planting and harvesting that minimally impact upon soil structure. Refraining from conventional ploughing due to its capacity to harm the connectivity and fertility of soil, low-till practitioners know the importance of soil's structural and ecological integrity for healthy plant growth. Like museum conservators who adopt protocols for handling museum objects, such practitioners distinguish parts of soil that are appropriate to move, disturb or touch. They consider soil moisture and previous frequencies of disturbance when making these decisions. Tilling, where it is deemed

65. T Harford, 'How the Plough Made the Modern Economy Possible', BBC World Service, 27 November 2017 <https://www.bbc.com/news/business-41903076>.

66. Kassam et al. define Conservation Agriculture in relation to three interlinked principles: 'no or minimum mechanical soil disturbance, biomass mulch soil cover and crop species diversification'. See A Kassam, T Friedrich and R Derpsch, 'Global Spread of Conservation Agriculture' (2018) International Journal of Environmental Studies 1.

67. See, for example, the work of M Puig de la Bellacasa, 'Making Time for Soil: Technoscientific Futurity and the Pace of Care' (2015) 45(5) Social Studies of Science 691-716. 
necessary, is more like a surgeon's knife and less like a twisting blade. This restraint is a practical form of recognition of soil's lateral connectedness: soil's fleshiness, its interwoven structure and the vulnerability of these connections. We might consider such practices as constituting a kind of spatial ethics with regard to the movement of bodies and tools (particularly machines) as they come into contact with soil.

Yet at the same time, in their most typical forms, low or no-till approaches tend to maintain monocultures, using large quantities of herbicides to eliminate self-sown species (instead of ploughing the soil for this purpose), and this can limit the diversity of soil dwellers. ${ }^{68}$ While such practices demonstrate a type of sensitivity towards certain soil needs, for the most part, they are still justified and articulated in instrumental and technical terms rather than in more explicitly ethical registers. Soil's value is considered to be derivative of its ability to perform certain functions for humans, or other valued species.

Acknowledging shortcomings of conventional low-till approaches for soil health, numerous farmers are adopting more ecologically informed practices sometimes termed 'beyond no-till', such as pasture cropping, cover cropping, and controlled traffic farming. Simon Mattsson, a second-generation sugar cane grower near Mackay, Queensland, initiated major changes to his farming practice due to concerns about the declining productivity of the land, with sugarcane production declining 9 per cent every five years. ${ }^{69}$ Harvests declined even after adopting several soil conservation measures such as cover crops, mulching and reduced tillage. ${ }^{70}$ This decline prompted him to embark on a global journey to learn about soil biology, funded by a Nuffield Scholarship. In his travels Mattsson learned from regenerative farmers about practical ways to integrate crop and cover crop biodiversity into a commercial farming system.

Upon returning home, Mattsson made several changes. He reconfigured machinery to reduce its impact on the earth, using controlled-track technology to limit compaction of the soil to narrow zones under the tracks, in recognition of the sensitivity of soil structures to being damaged by machinery ${ }^{71}$ especially after rain. He experimented with growing numerous plant species alongside the sugar cane: radish, turnip, soybeans, chickpea, vetch, oats, rye and sunflower. He now grows a commercial crop of sunflowers within one metre of the rows of sugar cane. The sunflower complements the sugarcane through being an annual plant that has a much faster growth rate compared to the sugar cane, shading the soil when the cane is young, and providing numerous other benefits (including its spectacular appearance when viewed from a distance, lending itself to a surprising artistic collaboration which also sheds light

68. S Sánchez-Moreno, J Castro, E Alonso-Prados, JL Alonso-Prados, JM García-Baudín, M Talavera and VH Durán-Zuazo, 'Tillage and Herbicide Decrease Soil Biodiversity in Olive Orchards' (2015) 35 Agronomy for Sustainable Development 691-700.

69. F Sheehan, 'Simon Mattsson - Cane and Cover Crops', Weekly Times. Reproduced by the Australian Biological Farming Conference $2018<\mathrm{https}: / / \mathrm{www}$.australianbiologicalfarming conference.org/simon-mattsson.html> accessed 22 November 2020.

70. Reef Catchments (Mackay Whitsunday Isaac) Limited, Case Study: Simon Mattsson $<$ https://hcmif3k7kt343pwrn2ytkt39-wpengine.netdna-ssl.com/files/2020/05/Mattsson-casestudyFINAL1.pdf> accessed 22 November 2020.

71. The Research Council of Norway, 'Heavy Agricultural Machinery Can Damage the Soil, Nordic Researchers Find', ScienceDaily, 9 May $2011<$ https://www.sciencedaily.com/releases/ 2011/05/110505083737.htm>. 
on the work of justice to soil). ${ }^{72}$ Having different types of plants growing together in a field means that the crops do not 'mine' the soil in the way that a monoculture does. ${ }^{73}$ But, more importantly, the soil ecosystem is more diverse, because each type of plant attracts a different range of microbes via the sugars exuded by its plant roots. ${ }^{74}$ These microbes help to build better soil structure, storing some of the sugars as long chain carbon compounds that can sequester carbon from the air. ${ }^{75}$ Bob Cannard, a farmer interviewed in the documentary Symphony of the Soil, explains how diverse crops can feed the soil:

In my gardens I grow two things all the time $-50 \%$ for people - which is the potato in this case, and $50 \%$ for nature - the soil improvement cycling crops. Very important - without a balance between the two, things will collapse. In my gardens and in the gardens of the future I believe, we need to recognize and feed nature as we feed humanity. I grow this mixed crop of soil improvement plants - you can call them weeds - they're mustards and vetches and clovers and a wide range of different plants in here. ${ }^{76}$

This description suggests acknowledgement of the need for distributive justice towards soil in farming, widening the range of beneficiaries of gardens' productivity so that the crops grown feed both humans and nonhumans. This approach challenges widely-held assumptions that cropping should involve humans harvesting the entire product of any given field, and that humans should compete according to a 'zero sum' calculus with the livelihoods of other species. ${ }^{77}$

Adopting a range of soil-sensitive practices and adapting these practices to signs of the condition of the soil, farmers can begin to inhabit attentive orientations to soil that are good bases for the recognition of soil as ethically significant, as an end in itself (in addition to as a means of making a living). Modifying practices iteratively upon receiving feedback from the land itself, farmers build a phronesis involving interpretive skills as well as greater receptivity and respect towards soil. Writing about Polyface Farm, where complex ecological relationships are woven into a farming enterprise, Romand Coles writes of a dynamic 'attentiveness from which new forms of understanding and practice begin to emerge that are more finely tuned to qualities of relationality, dynamics, interpenetration, complexity, fragility, reciprocity, and care than most of those that are dominant today'. ${ }^{78}$

72. L Ihlein, 'Sunset Symphony in the Sunflowers' (2017) <http://lucasihlein.net/SunsetSymphony-in-the-Sunflowers $>$ accessed 18 April 2021.

73. R Dybzinski, JE Fargione, DR Zak, D Fornara and D Tilman, 'Soil Fertility Increases with Plant Species Diversity in a Long-Term Biodiversity Experiment' Oecologia (2008) <http:// www.cbs.umn.edu/sites/default/files/public/t2138.pdf $>$ accessed 24 April 2021.

74. TR Turner, K Ramakrishnan, J Walshaw, D Heavens, M Alston, D Swarbreck, A Osbourn, A Grant and PS Poole, 'Comparative Metatranscriptomics Reveals Kingdom Level Changes in the Rhizosphere Microbiome of Plants' (2013) 7 ISME J. 2248-58.

75. CM Kallenbach, SD Frey and AS Grandy, 'Direct Evidence for Microbial-Derived Soil Organic Matter Formation and its Ecophysiological Controls' (2016) 7 Nature Communications 13630.

76. B Cannard, Symphony of the Soil, Dir. Deborah Koons (Lily Films, 2012), DVD.

77. This reference to livelihood as something that many species build comes from K Polanyi's Livelihood of Man (ed. HW Pearson, Academic Press 1977), which is explored by E Miller in Reimagining Livelihoods: Life beyond Economy, Society, and Environment (University of Minnesota Press 2019).

78. R Coles, Visionary Pragmatism: Radical and Ecological Democracy in Neoliberal Times (Duke University Press 2016) 101. 
Consistent with our discussion above about reparation as a turn towards attending to the previously excluded and violated other, soil-sensitive farming often involves new practices of observing soil. This includes noting signs given by indicator species such as plants or parasitic nematodes and engaging in responsive tinkering to amend soil - in response to yellowing leaves, for example - noting responses within a time period in which any change would have produced an effect. Exploring receptive practices of care for worms, Abrahamsson and Bertoni write of the embodied learning involved in the work of incremental attunement:

[T] his knowing takes the shape of a co-constructed, mutual, on-going and dynamic effort to attune your caring with the activities of the worms. Still, one that is not reciprocal in any egalitarian way, but rather sensitive to differences. 'Learning to speak worm', here, means learning to become attuned to the subtleties of the worms' relation with the wormery, with the food, with the bedding, with their environment. And food is a language that worms understand. It is a 'language,' but one that is not inflected in words, sentences and grammar, but in the utterance of practices, in the less codified tinkering of everyday life. $^{79}$

A key form of tinkering that is assisting farmers in their interspecies interpretive work with soil is carried out by using tools such as microscopes, which provide glimpses of microbial life and clues as to its condition. Jan, a soil scientist and educator, provides farmers with low magnification microscopes as part of her workshops, and explained her motivation as one of sparking interest and motivation for independent inquiry:

When [farmers] look at samples [of their soil] they see mites, springtails, other invertebrates. To know the soil is alive doesn't mean anything in particular but it starts [farmers] off. They then start asking other questions. They really have to shift their thinking, gain confidence to listen to their own environment, to know their own soil, don't rely on others to tell them what to do, and not follow recipes. ${ }^{80}$

Key to this work is helping farmers attune themselves to soil, renewing and redisclosing spatial and bodily understandings and assisting with the development and habituation of new practices which can help release the tight grip of control that can inhibit openness to more just interspecies relations in agriculture. Through spending greater time in careful observation, and attuning their bodies accordingly, practitioners can 'learn to be affected' by the condition of soil inhabitants, in modes of engagement that Bruno Latour has insightfully theorized. ${ }^{81}$ Here he discusses an example of a 'longitudinal' wine tasting 'that allows you ... to acquire a nose and a palate': ${ }^{82}$

[T] hanks to the multiplication of instruments, we have become capable of registering new distinctions ... The more instruments proliferate, the more the arrangement is artificial, the more capable we become at registering worlds. Artifice and reality are in the same positive column, whereas something entirely different from work is inscribed on the debit side: what we have there now is insensitivity. ${ }^{83}$

79. S Abrahamsson and F Bertoni, 'Compost Politics: Experimenting with Togetherness in Vermicomposting' (2014) 4 Environmental Humanities 134.

80. Interviewee 'Jan' in AT O'Brien, Ethical Relationships to Soil in the Anthropocene (PhD dissertation, Australian Catholic University 2017) 113-14.

81. For more on 'learning to be affected', see B Latour, 'How to Talk About the Body? The Normative Dimension of Science Studies' (2004) 10(2-3) Body \& Society 205-29.

82. B Latour, The Politics of Nature: How to Bring the Sciences into Democracy, trans Catherine Porter (Harvard University Press 2004) 84.

83. ibid 85 (original emphasis). 
Latour celebrates various ways in which interpretive skills can be enhanced through the careful use of the senses, and through employing certain tools. As technological means can enable humans to register subtleties and distinctions, they can help us to 'register worlds' where we might otherwise have difficulty doing so. For practitioners accustomed to prescriptive approaches to agriculture, learning of the mystery of soil communication through scientific instruments can be initially dissatisfying, since these tools provide fleeting clues but no definitive answers regarding what might be needed by the soil ecosystem. Action that flows from such observation is necessarily tentative, iterative and experimental. Nevertheless, this assertiveness feeds into the possibility of developing agricultural practice into more of a craft-based, open-ended receptive phronesis. Such approaches are slower than typical modern agricultural approaches, involving what Puig de la Bellacasa terms the 'pace of care'. ${ }^{84}$ The interpretive difficulty of understanding soil heightens soil's alterity, reminding farmers of how much remains unknown in any interaction with soil organisms. Increased awareness of epistemic limits tempers aspirations to mastery and control in agroecosystems, calling into question the will to order and determine the lives of these unknowable species.

While the problem of extending human moral imaginations to comprehend injustices outside frames of reference conventionally considered to demarcate the domain of justice is not unfamiliar to the task of justice, ${ }^{85}$ the high level of ontological difference between soils and humans presents considerable challenges for transitional justice to soils. And, although all processes of justice involve communicative gaps, such gaps are multiplied many times when it comes to soil. Public processes of transitional justice between humans often rely on intersubjective exchange between victims and perpetrators as a key element of the accountability process, bringing moments of identification and catharsis and heightening affective intensities. The lack of this kind of intersubjective exchange with soils means that, initially at least, efforts to do justice to soil might feel affectively dissatisfying.

Another challenge for transitional justice to soil is that little of the public discourse regarding soil conservation engages public ethics or the narratives that animate them. Education on soil conservation is commonly directed towards specialized audiences and concerned with alleviating cost pressures in farming enterprises, demonstrating business cases for farmers and explaining soil conservation scientifically. There is however a small but growing literature that seeks to engage the broader public regarding soil care. Public descriptions of soil that detail its aesthetically rich, surprising and interactive dimensions can do some work to help shift human relations that are stuck in control-oriented and static relations with soil. We can see this in the language encouraging care for soil by some writers and educators. David Montgomery writes, 'Look closely and you find a whole world of life eating life, a biological orgy recycling the dead back into new life. Healthy soil has an enticing and wholesome aroma - the smell of life itself'. ${ }^{86}$ The personification of soil microbes is a common device to encourage engagement, often used by soil educators invoking sensitive soil bodies. ${ }^{87}$ Yet identification as a primary route to sympathy tends to preclude the development of

84. M Puig de la Bellacasa (n 67) 691.

85. See A Waldow and D Schlosberg's piece 'The Subject of Multispecies Justice: Moving Beyond Individualism with Sympathetic Imagining' in Celermajer et al., 'Justice Through a Multispecies Lens' (n 3).

86. D Montgomery, Dirt: The Erosion of Civilizations (University of California Press 2007) 1. 87. See AT O'Brien, 'Ethical Acknowledgment of Soil Ecosystem Integrity amid Agricultural Production in Australia' (2020) 12(1) Environmental Humanities 275. 
sympathetic bonds across difference. Instead, respect for alterity and curiosity about difference, as well as the cultivation of a practical willingness to try different ways of being in community, are better preconditions for justice than is identification. ${ }^{88}$

An ethics centring soil as a subject of justice, while a nascent current in the ways in which many farmers and educators describe and justify conservation agriculture, ${ }^{89}$ is yet to be sufficiently developed. As such, beyond farming communities, a public reckoning with soil degradation, examining the ways in which violence to soil is institutionalized and upheld by common modern beliefs and practices is still difficult to imagine, at least in the imminent future. Yet as more land-based practitioners learn to protect and promote soil biodiversity, they can demonstrate tangible possibilities for multi-species flourishing and justice to soil, while showing by contrast what can be missing when systemic violence to soil is a norm.

\section{CONCLUSION}

Taking an eco-centric post-humanist approach to the adaptation of transitional justice to harms committed against more-than-human beings, we have argued for a shift from transformations on the plane of 'ideas' about others and about the norms of justice, to transformations on the plane of practices and embodied relationships. The practices described above provide an intimation of how this shift might occur, even in the absence of an explicitly ethical framework. Nevertheless, one might still ask, can these intimations of change be considered to be anything like transitional justice? Transitional justice in the human sphere typically utilizes the public domain as a space in which injustice can be named, and later, collective self-understandings can be called into question, with ideologies driving injustice problematized. Practices of symbolic reparation (as well as the more full-blown mechanisms like truth commissions) mobilize the tools of the public sphere, including the mass media, as platforms for widening an affectual and ethical transformation in the populace.

With respect to the example of soil that we have discussed in order to illustrate our thesis, even where there are changes, they are overwhelmingly occurring in the private sphere. Witnessing qualitatively different kinds of well-being and abundance on the land, many farmers experience sudden realizations that past practices have suppressed soil and land capabilities. Sometimes these individual experiences move into specialized practitioner groups, which might be seen as constituting types of 'publics', mediated by the internet as well as by in-person gatherings. For the most part, however, such networks do little by way of broader public engagement. Anna Krzywoszynska has written of the limited reach of such 'care networks', and how this reduces their capacity to bring about societal transformation to generate ethical concern for soil:

While this attentiveness is producing some transformative effects, its potential is limited by the configuration of the soil care network. As long as soil care is configured primarily as farmers' concern [and not a broader societal concern], the potential of attentiveness in generating ethical regard to the needs of soil biota will be limited. ${ }^{90}$

88. For an exploration of soil's alterity and ethics, see M Smith, 'Dis(appearance): Earth, Ethics and Apparently (In)Significant Others' (2011) 50 Australian Humanities Review 23-44. 89. AT O'Brien (2020) (n 87) 267-84.

90. A Krzywoszynska, 'Caring for Soil Life in the Anthropocene: The Role of Attentiveness in More-than-Human Ethics' (2019) Transactions of the Institute of British Geographers 1-15. 
Yet publics are being forged in unusual ways. There are some budding collaborations between artists and farmers specifically dedicated to engaging larger publics in the transformations taking place through regenerative practices and thereby altering the myths and narratives within which soil is currently located. Simon Mattsson, whose experience is discussed above, has worked with two artists, Lucas Ihlein and Kim Williams, on a chemical-free demonstration plot of sugar cane growing at the Mackay Botanical Gardens, planted and cared for with assistance from members of the Mackay community, and on a musical event - Sunset Symphony in the Sunflowers, at his farm. These efforts offer aesthetic enjoyment and community, cultivating a receptive environment in which participants might begin to perceive the interspecies conviviality at work when more soil-sensitive modes of farming are adopted. Although not framed in these terms, these events contribute to the work of justice. In their write-up of the symphony event, Ihlein (one of the artists) and Mattsson state:

The pay-off (besides the pleasure of the experience itself) is that having the sunflowers there attracts human bodies onto the farm, where they are inevitably prompted to ask the question: 'Tell me again, why did you plant sunflowers in among the sugar cane?' At this point, you've got them! Now a discussion begins about how to farm better for the health of the soil, and who knows where that might lead? ${ }^{91}$

Another project, Earth Canvas, brings together artists and regenerative farmers in South East Australia, and invites members of the public to take part in Open Days where they engage with the farmers, the artists and the practices so as to create a rich shared experience. ${ }^{92}$ One of the artists, Jenny Bell, who spent time at Mt Narra Narra station created Lifeblood, a vibrant painting expressing the vivid aliveness of what lives as soil. ${ }^{93}$ Reflecting on the experience, Bell writes,

The lifeforce beneath our feet was the hidden force driving this farm ... Lifeblood seeks to celebrate this, imagining a fragment of the world beneath our feet, its microbes, its symbiotic relationship and its interaction with the atmosphere - the interface on which all life on earth depends. ${ }^{94}$

She then describes how the painting includes a portrait of the human farmers, although looking at it, it is difficult to tell which image is them and which the beings of the soil.

Unlike more formal processes of transitional justice, the work here is emergent and oriented towards creating spaces of receptivity in which curious questions lead to deeper conversations. This responsiveness is part of the artists' approaches. Williams states:

A key thing in conversational work is listening - because it takes a lot of careful, patient and deep listening to form relationships with people and take it somewhere. I guess rather than challenging in a confrontational way, one thing we're doing is showing what's possible in agriculture, perhaps it's more inspiring rather than confronting. ${ }^{95}$

91. L Ihlein and S Mattsson, 'Sunflowers as Agricultural and Cultural Change Agents' in Futurelands 2: An Initiative of the Kandos School of Cultural Adaptation (2017) 21.

92. See Earth Canvas <https://earthcanvas.com.au/>.

93. Photos of Lifeblood and work created by other artists can be viewed at <https://earth canvas.com.au/art-exhibition/\#gallery>.

94. Earth Canvas Exhibition Catalogue, Albury Library Museum, p. 12.

95. K Williams, in Sugar vs the Reef? Exhibition Catalogue (Mackay Regional Council 2018) 6. 
Where recognition of injustice is still not widespread but is nascent, art can function as a powerful bridge and tool of disclosure, connecting the broader public with underappreciated worlds of soil. As Gillian Sanbrook, a farmer and Chairman of Earth Canvas puts it, 'in the same way that regenerative farmers have a symbiotic connection with their land and the animals they raise, artists must attempt to bridge the gap between themselves and the subject of their art'. ${ }^{96}$ Such work literally moves people, bringing them physically into spaces where they can perceive in their bodies what it might mean to take soil biodiversity seriously in agriculture.

Our contention is not that these practices of relational care, aesthetic encounter and interspecies conviviality are sufficient to account for the wrongs of the past, nor to provide the foundations for a transformed future. They are rather intimations, openings, suggestive practices that may iterate into larger openings. In the words of Coles, these receptive spaces of community participation generate '[resonant] fields of creative interaction between people and the land', carrying new possibilities for justice with them. ${ }^{97}$

96. Earth Canvas Exhibition Catalogue, Albury Library Museum, p. 5.

97. R Coles (n 78) 103. 